УДК 81'37:641/642

\title{
ЧАСОВА СЕМАНТИКА МИНУЛОГО В СУЧАСНОМУ КУЛІНАРНОМУ ДИСКУРСІ
}

\section{Оксана Остроушко}

\author{
Криворізький державний педагогічний університет \\ Kryvyi Rih State Pedagogical University \\ пр. Гагаріна, 54, Кривий Ріг, 50086, Украӥна \\ ostroushko.oksana@gmail.com
}

\begin{abstract}
Остроушко О. Часова семантика минулого в сучасному кулінарному дискурсі

У статті розглянуто репрезентацію часової площини минулого в текстах кулінарних рецептів, розміщених на трьох авторських кулінарних Інтернет-сайтах. Акцентовано увагу на тому, що досліджувані тексти мають чотирикомпонентну структуру: назва, вступ, перелік інгредієнтів, опис дій; часова семантика минулого виявляється у вступній частині авторського кулінарного рецепта. Проаналізовано три основні аспекти семантики минулого: традиції, спогади, досвід - у їх зв'язку з широким соціальним контекстом, комунікативними настановами мовця та образом адресанта.

Ключові слова: кулінарний дискурс, темпоральність, часова семантика, кулінарний рецепт.
\end{abstract}

Остроушко О. Часовая семантика прошлого в современном кулинарном дискурсе

В статье рассматривается репрезентация временного пространства прошлого в текстах кулинарных рецептов, размещенных на трех авторских кулинарных Интернет-сайтах. Акцентируется внимание на том, что рассматриваемые тексты имеют четырехкомпонентную структуру: название, введение, перечень ингредиентов, описание действий; временная семантика прошлого выявляется во вступительной части авторского кулинарного рецепта. Анализируются три основных аспекта семантики прошлого: традиции, воспоминания, опыт - в их связи с широким социальным контекстом, коммуникативными намерениями говорящего и образом адресанта.

Ключевые слова: кулинарный дискурс, темпоральность, временная семантика, кулинарный рецепт.

Ostroushko O. Temporal semantics of the past in modern culinary discourse

The article deals with the representation of the temporal plane of the past in the texts of culinary recipes placed on three author culinary websites. The culinary recipe ceases to be an impersonal instruction, it is presented to a wide audience by a 
certain person, who brings to communication his / her own estimates and views, demonstrates his / her own experience, relays certain values and so on. This causes a change in the traditional structure of the recipe text, which becomes four-component and consists of the name, introduction, list of ingredients, description of actions.

The introduction is the most individualized part. It highlights author's position. The temporal semantics of the past seems to be an important semantic component, in which three main aspects are emphasized: traditions, memories, experiences. Many of the dishes are described by the authors as traditional, ancient, and classic. Retelling of origin of dishes, origin of the names of dishes emphasizes their long standing.

The recipe authors give personal memories, tell about certain past events of their own lives, and describe their own culinary experience, attempts, experiments, feelings, obtained results. Cooks get rid of the abstractness of the text-instruction, bring it closer to real life, which moves from the past to the future, to some extent "enliven" the text, bringing an emotional component to it. Childhood memories hold a specific place, mostly what and how mother and / or grandmother cooked.

Such representation of the past emphasizes the importance of preserving and transmitting traditions; it is one of the means of forming the image of the addressant as an experienced cook, forming the addressee's confidence in the proposed recipe. It facilitates a solution of the communicative aim - to determine the addressee to prepare the dish.The temporal semantics of the past in the texts of modern culinary Internet recipes reveals connections with the broad social context, communicative attitudes of the speaker and the image of the addressant. recipe.

Key words: culinary discourse, temporality, temporal semantics, culinary

Постановка проблеми, аналіз наукових публікацій. Кулінарний (гастрономічний, глютонічний) дискурс в останні десятиліття став об'єктом зацікавлення науковців різних сфер гуманітарного знання: до традиційних антропологічних, етнографічних праць додалися філософські, соціологічні, культурологічні, лінгвістичні, літературознавчі та ін. Серед найбільш значущих, на наш погляд, варто згадати широковідомий збірник статей, упорядкований Ф. Олгофом і Д. Монро "Їжа i філософія” [Yizha / Їжа 2011], докторську дисертаційну працю В. Ніколенка [Nikolenko / Ніколенко 2015], літературознавчі розвідки В. Дмитренко, С. Ковпік, С. Філоненко (наприклад, [Kovpik / Ковпік 2018]). Лінгвісти переходять від вивчення груп лексики сфери харчування (тематичні групи назв продуктів харчування, страв, посуду, кухонного начиння тощо) до дослідження етнолінгвістичних, лінгвокультурологічних, комунікативно-прагматичних характеристик комунікації у сфері

๑) О. Остроушко, 2019. 
кулінарії та споживання їжі (праці В. Жайворонка, С. Руденко, Л. Струганець та ін.). Основні напрями лінгвокультурологічного та етнолінгвістичного дослідження когнітосфери “Їжа" в українській мові окреслено у статті 3. Козирєвої [Kozyrieva / Козирєва 2014].

Тема харчування наразі $€$ надзвичайно популярною у сфері масової комунікації, свідченням чому слугує велика кількість різноманітних телепередач та їх окремих фрагментів кулінарного спрямування, збільшення числа спеціалізованих друкованих засобів масової інформації (які, щоправда, “живуть” нетривалий час) та кулінарних книг, а також зростання кількості кулінарних Інтернет-сайтів і спільнот у соціальних Інтернетмережах. Особливості й закономірності цієї комунікації, іiї жанрової і мовної організації поки що не знайшли достатнього висвітлення в науковій літературі.

Водночас зі зростанням масовості, кулінарний дискурс, за нашими спостереженнями, все більше індивідуалізується: зокрема, кулінарний рецепт перестає бути знеособленою інструкцією, його представляє широкій аудиторії певна особистість, що вносить у комунікацію власні оцінки й погляди, демонструє власний досвід, ретранслює ті чи ті цінності тощо. Це спричиняє зміну традиційної структури рецептурного тексту, у якій з'являється вступна частина, покликана вплинути на адресата, спонукати його до дії - приготувати страву за пропонованим рецептом. У контексті телевізійних передач здебільшого змін зазнає i власне інструктивна частина: спонукальні конструкції супроводжуються різними коментарями, поясненнями, оцінними судженнями тощо.

Такі трансформації значно ускладнюють семантику сучасного кулінарного рецепта. Однією 3 прикметних рис, на наш погляд, виявляється часова площина. Для кулінарного рецепта характерна особлива темпоральна структура 3 акцентами на послідовності дій, тривалості дій та / або процесів, наприклад: Добре вимісити туге тісто, спочатку міксером, а потім місити руками, або ж одразу лиш руками, доки воно почне ставати однорідним. <...> Загорнути тісто в харчову плівку та поставити в холодильник на 1-2 години, а можна на 
ніч (або аж⿻ до 3-x діб) (“Гречана локшина") (3). Але сучасний кулінарний рецепт засвідчує актуалізацію часової семантики минулого, що, на перший погляд, не видається логічним.

Мета дослідження. Наша наукова розвідка присвячена особливостям репрезентації одного 3 аспектів темпоральної семантики - семантики минулого - в текстах кулінарних рецептів, розміщених у мережі Інтернет на авторських україномовних кулінарних сайтах. Мета статті - виявити й описати ключові акценти семантичної площини минулого в кулінарних Інтернет-рецептах у іï зв'язку з комунікативними настановами мовця та структурою тексту. Матеріалом аналізу стали рецепти 3 кулінарних сайтів Євгена Клопотенка (1), Маріанни Душар (2), Вікторії Попін (3).

Виклад основного матеріалу. Кулінарний рецепт - це передусім текст-інструкція. Він ретранслює інформацію про те, iз яких інгредієнтів, за допомогою якого приладдя, яким способом і як швидко можна приготувати ту чи ту страву. Але це інструкція, вписана в контекст соціального життя людини: рецепти виявляються прийнятними чи неприйнятними для людини 3 огляду на іï матеріальні статки (інгредієнти страви можуть коштувати доволі дорого), соціальний статус (страви виступають маркером, соціальним знаком належності до певної групи), ідеологічні, зокрема, релігійні, переконання (прибічники веганства, вегетаріанства не вживають або суттєво обмежують уживання іжі тваринного походження, іудаїзм диктує своїм прибічникам суворі правила відбору продуктів харчування та технології приготування страв, православ'я визначає періоди посту) тощо.

Кулінарні книги як зібрання рецептів, 3 одного боку, постають чи не найяскравішим прикладом текстів суто утилітарного призначення (це керівництво до дії), 3 іншого, являють собою текстове відображення різних аспектів культури. На думку А. Вессел і А. Вішарт, кулінарні книги можуть бути потрактовані як важлива частина музейної колекції: вони мають матеріальну й соціальну цінність, дають можливість виявити важливі сторони щоденного життя: ставлення до їжі, економіку домашнього господарювання, роль жінки [Wessell, Wishart

(С) О. Остроушко, 2019. 
2010 : 1]. Кулінарні книги створюють прообрази-макети їжі, відображають спосіб харчування нації, втручаються в нього, дебатують тему їжі й дому-родини [Wessell, Wishart 2010 : 16].

Кулінарні Інтернет-сайти як своєрідні кулінарні онлайнкниги демонструють різні сторони культури харчування наших сучасників, зокрема культури домашнього куховарства, засвідчують зміни і матеріальної, і духовної складових. У плані матеріальному завдяки глобалізаційним змінам на кухні сучасного українця з'явилися авокадо, кальмари, соєвий соус, стали популярними суші, піщ̧а, макаруни, технічний прогрес дозволив послуговуватися кухонними комбайнами, скибкорізками, блендерами. У плані духовному кулінарний дискурс пропагує певні цінності й ідеї: збереження національнокультурної ідентичності, формування нової “глобальної кухні”, гастрономічний туризм, рух слоу-фуд, домашне куховарство як хобі і як спосіб здорового харчування.

Відповідні комунікативні настанови впливають на семантику і структуру тексту сучасного кулінарного рецепта. Усі проаналізовані рецепти мають чотирикомпонентну структуру: назва, вступ, перелік інгредієнтів, опис дій. Вступна частина найбільш індивідуалізована й найкраще виявляє авторську позицію. Це той компонент рецепта, який $є$ його обгрунтуванням, він може містити пояснення до назви страви, іiі загальну характеристику (призначення, смак, оцінка і т. ін.), заклики до адресата, як-от: Кашик - овочевий салат, який дуже часто готують в Туреччині. Всі овочі нарізаються максимально дрібно - ие одна з головних умов. Страва дуже проста, але при цььому універсальна. 3 таким салатом прекрасно поєднуються м'ясні та рибні страви. Кашик дуже соковитий, лимон надає йому приємної кислинки. Загалом, неодмінно приготуйте цей прекрасний овочевий салат (“Кашик - овочевий салат”) (1). Як бачимо, конструюється темпоральна семантика теперішнього постійного, позачасового: коли б ви не приготували страву, вона матиме саме такий смак, такий вигляд і споживати iї чи подавати до столу варто саме так, як написав автор. У загальному описі страви може з'являтися і часовий пласт майбутнього, спрямований на можливий i бажаний 
результат: Попри свою простоту, ией салат дуже смачний та універсальний <..> Все завдяки медово-гірчичній заправці з часником та кропу, які надають салату з огірків незвичайний смак. Це салат який відмінно підкреслить смак страв української, польської чи навіть чеської кухні. Він підійде до свинини, просто приготовленої риби, птиці, чи навіть просто до печеної, вареної чи смаженої картоплі. Це щзоднний салат 3 цікавим смаком до буденного столу (“Салат з огірків 3 медовогірчичною заправкою”) (3).

Водночас проаналізовані тексти рецептів доволі часто актуалізують часову площину минулого, що особливо яскраво засвідчують вступні частини. Можемо виокремити три основні аспекти: традиції, спогади, досвід.

Збереження національних кулінарних традицій - важливе завдання сучасного кулінарного дискурсу з огляду на контекст глобалізаційних змін i загальних намагань зберегти національно-культурну різноманітність. Наприклад, Маріанна Душар на своєму сайті у розділі "Про мене" заявляє про це так: Хочу, щоб з нашого столу не зникали наїоки наших бабусь, а лексикону - їхні назви (2). Багато рецептів на сайті - за іï тлумаченням, "переписів" - якраз і зберігають, і відроджують, і поширюють знання про давні традиційні страви Галичини. Вступні частини містять тлумачення назви, часто - історію виникнення, інформацію про варіації та територіальні й часові видозміни.

Часова належність до минулого репрезентована здебільшого лексичними засобами: словами різних частин мови iз семами “минулий”, “давній”. Так, вступний коментар до рецепта Пажиброди в Маріанни Душар містить загальне визначення страви й переказ двох версій походження назви: Пажиброда (Parzybroda) - “обпечена борода" - давня зупа львівських вірменів, дуже смачна, ароматна і поживна (2), а рецепт під назвою "Маїна, навіть дві маїни: єврейська i буковинська" авторка починає 3 іншої загальної часової характеристики давності й визнаності страви: Маїна святковий завиванець з воловим м'ясом, яка вважається класикою єврейської буковинської кухні (3) У Свгена

() О. Остроушко, 2019. 
Клопотенка рецепт “Салат Капрезе 3 персиками” також починається із загальної вказівки на давність рецепта: Капрезе це італійська класика (1).

Багато страв автори досліджених сайтів характеризують як традиційні: Сирна плесканка - один із традиційних “мешканців” Великоднього кошика, менше у Львові, а більше в околииях (“Великодня сирна плесканка з кмином”) (2). Мізерія, від слова мізер, - це традиційний польський салат з огірків, який з'явився в польській кухні приблизно у XVI cm. ("Мізерія") (3). Для тих хто не знає, пєрнік - це традиційна польська пряна різдвяна випічка зі спеціальною сумішшю спещій ("Різдвяний пряний кекс з чорносливом") (3).

Давність тієї чи тієї страви підкреслено через перекази історії іï виникнення, походження назви, при цьому можуть уживатися мовні знаки часової локалізованості, як-от: Згідно з деякими історичними довідками своєю назвою ией суп зобов'язаний Марі Жанні Дюбарі - фаворитці французького короля Людовика $\boldsymbol{X V}$. Саме їй приписують авторство иъього peцепта (“Крем-суп 3 цвітної капусти “Дюбарі”) (1); Якщо вірити історичним джерелам, то перша згадка иієї страви датується 1788 роком (“Картопляний гратен Дофінуа”) (1). Хоч яловичина по-бургундськи дуже відома франиузька страва, насправді вона не надто давня й вважається, щчо вона родом всього лише десь з 19-го століття ("Яловичина побургундськи (Boeuf Bourguignon)") (3).

Розповіді про автентичну страву та іï видозміни вибудовуються передовсім у граматичній площині минулого: Традиційний рецепт айолі складався з оливкової олї, часнику $i$ солі, перебитих у ступці. Трохи пізніше до нього стали додавати яєчні жовтки, гірчицю і лимонний сік, від чого його стали часто називати майонезним соусом (“Соус айолі”) (1).

Але традиційність не означає неможливість видозмін. Окрім того, традиційність подекуди набуває негативної оцінки, потрактовується як застиглість, як те, що набридає. Саме тому презентовані на сайтах рецепти почасти є індивідуальними авторськими варіаціями давніх або всім відомих рецептів, звичних страв. У такому разі у вступній частині рецепта 
перетинаються кілька площин минулого: перевірена часом традиційність рецептури та власний досвід автора допису: Традиційний рецепт запеченої картоплі досить приївся. Тому я трохи удосконалив рецепт $i$ зробив його иікавіше ("Картопля 3 грибами") (1). Я вирішив трохи змінити традиційний рецепт капусняка і приготувати його без крупи, додавщи до овочевої піджарки звичайні печериці (“Капусняк з грибами”) (1).

Такі тексти демонструють органічний взаємозв'язок трьох часових площин минулого, теперішнього й майбутнього. Традиційність рецепта, що передусім сприймається як багатократна апробація його протягом тривалого часу багатьма людьми, його визнаність і відомість, у поєднанні з описаними минулими кулінарними спробами й видозмінами автора допису творять комунікативне теперішнє читача, презентуючи текстінструкцію “до діï” 3 тим, щоб адресат, відтворивши в майбутньому необхідні дії, зміг насолодитися результатом: Запечена картопля - традиційна для української кухні страва. Як правило, ми запікаємо ї̈ зі шматочками сала. Безумовно, це дуже смачно, але я пропоную більш цікавий варіант. Приготуйте ароматну картоплю з розмарином і мочарелою ця чудова закуска підійде для святкового столу як гарнір, також - в якості закуски під улюблений фільм ("Картопля з розмарином і моцарелою") (1).

Другий яскравий аспект актуалізації часової площини минулого - особисті спогади авторів рецептів. Через розповіді про певні минулі події власного життя кулінари позбавляються від зайвої абстрактності тексту-інструкції, наближають його до реального життя, спрямованого з минулого в майбутнє, певною мірою “оживлюють” текст, уводячи в нього емоційну складову.

Та чи та страва виявляється пов'язаною з якоюсь подією чи якимось періодом минулого життя оповідача. Це емоційно насичені спогади, що виявляється через уживання автором стилістично забарвленої лексики, слів із позитивними конотативними значеннями, підсилювальних часток, іноді вигуків, використання стилістичних фігур, як-от: Голубці в буряковому листі - дуже очевидна, але на жаль забута страва. Для мене вони - спомин про татову тету Катерину, яка їх

(C) О. Остроушко, 2019. 
варила щуоразу, коли ми приїжджали на гостину. Маленькі, соковиті голубчики, зі сметанкою.. ммм... ие направду дуже добре! (“Голубці в буряковому листі з кулешою”) (2).

Особливе місце посідають спогади про дитинство, а відтак - про те, що і як готувала мама та / або бабуся. Страви і смаки 3 дитинства максимально позитивні, досконалі, певною мірою, це ідеал, до якого слід прагнути. Це те, що дарує емоційну теплоту й радість, поєднані з відчуттям невідворотності плину часу. Так, Євген Клопотенко, представляючи рецепт "Великодній хліб за маминим рецептом" (прикметно, що і в назві наявна непряма вказівка на минуле), створює позитивний емоційний фон, навіть називаючи рецепт рідним: Мамин великодній хліб викликає у мене ностальгію за дитинством. Приємний запах випічки, яким заповнювався весь будинок в переддень Великодня неможливо забути і переплутати з чимось іншим. Можливо, у когось знайдеться більш оригінальний рецепт великоднього хліба, але мені хочеться поділитися з вами саме цим, рідним для мене рецептом. Хочу зізнатися, що і в иььому випадку мій дух новаторства трохи пересилив, $i$ я трохи змінив рецепт, замінивши звичайні фруктові иукати овочевими -морквяними й буряковими (1). Але, як бачимо, так само, як і в ситуації 3 аспектом традиційності, далеке минуле дитинства органічно поєднується з недавнім минулим особистого досвіду автора.

Зрідка, але автор презентує свої спроби виправити негативний минулий досвід: Я з дитинства не люблю вівсяну кашу. Вона для мене дуже в'язка і несмачна. I ось нічого не може ї̈ врятувати, навіть пармезан. Мучився я до тих пір, поки в моєму житті не з'явилася гранола - запечена вівсянка (“Гранола - як приготувати вдома") (1).

Подібні варіації “рецептів із дитинства" непоодинокі на сайті Євгена Клопотенка. Часом особисті спогади стають лише окремим прикладом спогадів покоління. А видозміни, внесені в рецепт кулінаром, удосконалюють страву: Ліниві вареники - це спогад з дитинства. Пам'ятаю, мама варила їх, коли часу не було зовсім. Мені здається, щзо така жс історія була у багатьох моїх однолітків. Що б там не було ия проста страва ліниві вареники дуже подобаються дітям, навіть тим, хто не сильно 
любить сир. Я вирішив трохи освіжнити рецепт з дитинства $i$ приготувати ліниві вареники з лимонною цедрою та йогуртовим соусом. Загалом, нічого складного, але старе знайоме блюдо звучить вже по-новому (“Ліниві вареники 3 йогуртовим соусом") (1).

На такі ж емоційно насичені ностальгійні спогади про дитячі роки натрапляємо i в переписах Маріанни Душар: В изьому місці моєї розповіді на мене налітає вир спогадів... Літа в Пістині, накритий цератою стіл під грушкою, довгі балачки моєї бабусі з тетою Левкою, походи на річку, а потім, через хиткий міст, до церкви і на луки. А ще я пам'ятаю смак Пістинської кулеші - або вмоченої в яйе $i$ засмаженої до шкірочки, з горнятком кисляку.. або ось такої з грибами $i$ бриндзьою (“Лисички, смажені на солонині, 3 кулешою i бриндзьою по Пістинськи”) (2). Прикметно, що оповідь не містить граматичних маркувань минулого часу: співвіднесеність із минулим маркується образним висловом налітає вир спогадів, дієсловом пам'ятаю.

Приготування страви “з дитинства" не просто дарує позитивні емоції i служить додатковим аргументом, аби спробувати приготувати за цим рецептом. Подібні рецепти виступають важливим засобом єднання поколінь. Це також збереження традицій, сімейних зв'язків.

Спогади автора - це також згадки про певні події, які спонукали до ознайомлення з тією чи тією стравою. Типовими $є$ згадки про подорожі та ознайомлення зі стравами різних народів: Сьогодні я вирішив згадати свою подорож до Америки i поділиться ще одним американським рецептом. ("Шоколадне печиво з мигдалем: як в Америці”) (1), Коли я навчався у Франції, я дуже часто робив випічку з пісочним тістом. Треба зізнатися, були у мене як успіхи, так $і$ невдачі. А потім $я$ дізнався один рецепт, який мені дуже сподобався французький яблучний тарт (“Яблучний тарт”) (1), Вперше таку канапку я спробувала в Копенгагені в делі відомого данського кулінара Клауса Мейєра "Meyers Deli", тоді я навіть не знала, щуо вона така культова. Смак ї̈ пам'ятаю й досі й не дарма! (“Велика данська канапка з запеченої свинини”) (3), Це

(C) О. Остроушко, 2019. 
та страва, яку жнивуи своє студентське літо в Мадриді, я ӥла майже не щьдня, як ие зрештою роблять і місцеві ("Іспанська тортилья з картоплею") (3).

Презентація страви іншого народу, яку автор скуштував, так би мовити, “в оригіналі”, у процесі комунікації сприймається як додатковий аргумент на користь рецепта, його автентичності. Такі оповіді виступають додатковим засобом характеристики автора дописів як досвідченого кулінара, обізнаного з різними національними кухнями, допомагають формувати образ авторитетного мовця, до якого слід прислуховуватися і порадам якого варто слідувати.

Третій аспект актуалізації часової площини минулого опис власного досвіду автора рецепта, його дій, спроб, почуттів, отриманих результатів і т. ін. Так, Маріанна Душар певну частину своїх переписів презентує, уживаючи граматичні форми минулого часу. Текст рецепта звучить не як позачасова інструкція, а як апробований опис дій конкретної особистості. Цим самим віртуальний текст кулінарного Інтернет-рецепта набуває форми авторської нарації, яка, тим не менше, орієнтована на адресата, тому містить і узагальнено-особові конструкції у формі 2-ої ос., і безособові конструкції 3 модальним значенням: Гарбуз покроїла $і$ трошка підварила в воді. Як вистигне - зблендерувала. Додала стільки ж молока (за об'смом), яйця з розрахунку 1 яйще на шклянку сумімі $i$ борошна стільки, щуоб тісто було трохи густіше, ніж зазвичай на налисники. Посолила, дала трошки цукру, пів шклянки олії $i$ дуже добре зміксувала. Смажила на гарячій пательні. Якщо вам налисники будуть погано перевертатися - додайте щее борошна. Надівання до таких налисничків може бути і солодке i солене, на ваш смак. Я зробила сир з кропом і підсмаженим сезамом - дуже мені смакує комбінація сиру $і$ сезаму. Добре посолила $і$ поперчила. Сезам треба смажити на сухій пательні постійно помішуючи, до легенького потріскування $i$ жовтуватого кольору. 3 солодким чаєм для неспішного недільного снідання - дуже смачно! ("Гарбузяні налисники, надівані сиром з кропом і сезамом”) (2). 
Євген Клопотенко в багатьох рецептах згадує про власні модифікації базового рецепта та отримані результати: Соус вінегрет - дуже проста і смачна заправка для салатів, яку я вирішив трохи доопрацювати. В результаті у мене вийшов на диво ніжний $і$ густий соус вінегрет з авокадо (“Соус вінегрет 3 авокадо") (1); Я трохи змінив традиційний рецепт $i$ замість шафрану, який продається далеко не скрізь, використовував куркуму. Вийшло просто божественно - ідеально для дорослих i дітлахів. (“Паелья з куркою і куркумою”) (1). Натрапляємо й на опис власного винаходу - авторської страви “Зелений салат з горохом і яблуками": Цей рецепт я придумав, коли ми 3 командою розробляли меню для мого ресторану. Мені захотілося зробити зелений салат 3 горохом. 3 зеленим горошком, зеленим яблуком, зеленим шпинатом і навіть зеленим маслом. Всі відтінки і смаки зеленого, які можуть бути 3 легкими акцентами циибулі та редьки. I иче вийшло настільки круто, щзо я просто був зобов 'язаний цุим поділитися (1).

Вікторія Попін, яка до кожного з презентованих рецептів подає дуже розлогі вступи з детальними описами всіх нюансів приготування, вибудовує оповідь у часовій площині теперішнього постійного. Але часом також є згадки про власні кулінарні спроби й експерименти: Ідея спекти хліб на пиві не покидала мене вже давно. Довго збиралась, довго гадала 3 якого пива почати, які додатки покласти. I ось він нарешті! Насичений смаком та ароматом хліб з нотками солоду та вкрапленнями сиру. У мене в сім' $і$ всі без винятку сиромани, тож зрозуміло, щзо хліб з'їли з ентузіазмом до останнього шматочка (“Хліб на пиві з сиром”) (3); Такий оселедець в азіатському стилі я вигадала з любові до корейської та японської кухні. Роблячи в черговий раз кімчі (в холодну пору року я роблю його по кілька 3-х літрових банок декілька раз за сезон), я подумала, щчо подібні інгредієнти будуть не менш вдало смакувати з оселедием. Так і повстав иеей рецепт дуже смачного, незвичайного та трішки пікантного оселедия (“Маринований оселедець в азіатському стилі”) (3).

Репрезентація минулого у вступній частині рецепта через опис мовцем своїх дій, кулінарних спроб і т. ін. виявляє різну

(c) О. Остроушко, 2019. 
функціональність: це може бути інформування (про зроблені модифікації, нові інгредієнти тощо), а також додаткова характеристика мовця як досвідченого та авторитетного кулінара.

\section{Висновки та перспективи подальших наукових} розвідок. Часова семантика минулого постає важливим компонентом семантики сучасного авторського кулінарного Інтернет-рецепта. У просторі Інтернет-комунікації кулінарний рецепт як традиційний текст-інструкція модифікується, утрачає знеособленість, пов'язується не тільки 3 тією чи тією національно-культурною кулінарною традицією, але й iз індивідуальним досвідом мовця - автора-ретранслятора рецепта. У структурі тексту з'являється вступна частина, у якій яскраво виявляється образ адресанта. У семантичній площині минулого акцентуються аспекти традиції, спогадів, досвіду. Подібна репрезентація минулого підкреслює важливість збереження й передачі традицій, $є$ одним із засобів формування образу адресанта як досвідченого кулінара, формує в адресата довіру до пропонованого рецепта, а отже, сприяє розв'язанню комунікативного надзавдання - спонукання адресата до приготування страви.

У подальшому потребують аналізу інші аспекти часової семантики текстів кулінарних рецептів, взаємозв'язки часових $\mathrm{i}$ модальних значень.

\section{Література}

1. Їжа i філософія: їжте, пийте i будьте щасливі / упоряд. Ф. Олгоф, Д. Монро, переклад П. Таращук. Київ : Темпора, 2011. 346 с.

2. Ковпік С. Поетика густативів (на матеріалі сучасної української прози) : монографія. Київ : ТОВ “НВП Інтерсервіс", 2018. 150 с.

3. Козирєва 3. Українська когнітосфера "Їжа" як предмет лінгвістичного дослідження. Науковий вісник кафедри Юнеско КНЛУ. Серія Філологія. Педагогіка. Психологія. 2014. Вип. 29. С. 48-55.

4. Ніколенко В. В. Гастрономічні детермінанти суспільного життя: соціологічний вимір : дис. ... д-ра соціол. наук : 22.00.01/ Дніпропетровський національний університет імені Олеся Гончара. Дніпропетровськ, 2015. 441 с.

5. Wessell A., Wishart A. Recipes for reading culinary heritage: Flora Pell and her cookery book. ReCollections: Journal of the National Museum of Australia. 2010. Vol. 5. N. 1. URL : http://recollections.nma.gov.au/issues/vol_5_no_1/ 
1. https://klopotenko.com/uk/

\section{Список джерел ілюстративного матеріалу}

2. https://panistefa.com

3. https://picantecooking.com/ua/

\section{References}

1. Yizha i filosofiia: yizhte, pyite i budte shchaslyvi/uporiadn. F. Ollhoff, D. Monroe, pereklad P. Tarashchuk. Kyiv : Tempora, 2011.346 s.

2. Kovpik S. Poetyka hustatyviv (na materiali suchasnoii ukrainskoi prozy) : monohrafiia. Kyiv : TOV "NVP Interservis", 2018. $150 \mathrm{~s}$.

3. Kozyrieva Z. Ukrainska kohnitosfera "Yizha" yak predmet linhvistychnoho doslidzhennia. Naukovyi visnyk kafedry Yunesko KNLU. Seriia Filolohiia. Pedahohika. Psyholohiia. 2014. Vyp. 29. S. 48-55.

4. Nikolenko V. V. Hastronomichni determinanty suspilnoho zhyttia: sotsiolohichnyi vymir : dys. ... d-ra sotsiol. nauk : 22.00.01 / Dnipropetrovskyi natsionalnyi universytet imeni Olesia Honchara. Dnipropetrovsk, 2015. $441 \mathrm{~s}$.

5. Wessell A., Wishart A. Recipes for reading culinary heritage: Flora Pell and her cookery book. ReCollections: Journal of the National Museum of Australia. 2010. Vol. 5. N. 1. URL : http://recollections.nma.gov.au/issues/vol_5_no_1/

Стаття надійшла до редакиії 15.10.2019 p. Прийнята до друку 19.11.2019 p. 